Aleksandar Zdravković ${ }^{1}$ Jovan Zubović ${ }^{2}$

Aleksandra-Bradić Martinović ${ }^{3}$
JEL: E62

DOI: 10.5937/industrija41-5057

UDK: 336.27:336.143(4-672EU) ;

330.43:336.2

Original Scientific Paper

\title{
Fiscal Reaction Function: Evidences from CESEE countries ${ }^{4}$
}

Article history

Received: 10 October 2013

Sent for revision: 12 October 2013

Received in revised form: 11 November 2013

Accepted: 15 November 2013

Available online: 6 December 2013

\begin{abstract}
The aim of this paper is to improve on the methodology set in previous attempts to estimate the impact of gross government debt to primary balances in a wide set of 21 CESEE countries. Since the result of the longlasting crisis in those countries is rising imbalance of public finances it is necessary to analyze what factors are causing such effects. Running the fixed effects, pooled and GMM regression it was found that both lagged government debt and output gap are positively related to primary balance. Moreover there was found evidence of non-linear relationship between primary balance and lagged debt, with fiscal fatigue occurrence at $70 \%$ threshold. Estimation of the augmented model shows that countercyclical response of primary balance is more pronounced in economic downturn relative to boom in cycle.
\end{abstract}

Keywords: fiscal reaction function, CESEE region, public finances

\section{Funkcija fiskalne reakcije: primer zemalja CESEE regiona}

Apstrakt: Cilj ovog rada je unapređenje metodologije postavljene u ranijim istraživanjima drugih autora za procenu uticaj javnog duga na bruto primarni bilans $u$ velikom skupu od 21 zemlje CESEE regiona. Jedna od posledica dugotrajne krize u tim zemljama je porast disbalansa javnih finansija te je neophodno analizirati koji faktori izazivaju takve efekte. Primenom regresije na panel podatke utvrđeno je da državni dug sa docnjom i autput jaz imaju pozitivan uticaj na primarni bilans. Takođe je potvrđena nelinearne veza

\footnotetext{
${ }^{1}$ Institute of Economic Sciences, aleksandar.zdravkovic@ien.bg.ac.rs

${ }^{2}$ Economics Institute, jovan.zubovic@ecinst.org.rs

${ }^{3}$ Institute of Economic Sciences, abmartinovic@ien.bg.ac.rs

${ }^{4}$ The paper presents the results of a study conducted as part of the projects 179001 , 179015 funded by the Ministry of Education, Science and Technological Development of the Republic of Serbia.
} 
između primarnog bilansa u i dug sa docnjom, sa pojavom fiskalnog zamora na nivou od $70 \%$. Procena uvećanog modela pokazuje da je kontracikličan odgovor primanog bilansa izraženiji tokom ekonomske krize u odnosu na period prosperiteta.

Ključne reči: funkcija fiskalne reakcije, CESEE region, javne finansije

\section{Introduction}

Economic crisis that recently hit the world left many European countries, both emerging and advanced, with public finance imbalances and sloppy growth prospects. Efforts of European countries to speed up economic growth and fight recession and rising levels of public debt revived academic discussion on instruments and efficiency of fiscal policy; interrelations between primary balance, government debt and output fluctuations have become subject of many researches in recent years.

Main objective of our work is to analyze how primary balances in emerging European economies adjust to dynamic of gross government debt and economy cycle, based on empirical estimation of fiscal reaction function. The fiscal reaction function shows the response of the primary budget balance to GDP ratio to a set of macroeconomic and institutional variables, of which the debtto-GDP ratio and the output gap are the most important ones (Eller and Urvova, 2012). It describes the average response of actual primary balances after controlling for cyclical fluctuations, the lagged public debt-to-GDP ratio, and political and institutional variables (Medeiros, 2012).

Estimation of fiscal reaction function for advanced and emerging economies was under attention of several empirical works in last couple of years, especially as a part of the wider framework of debt sustainability analysis (Celasun, Debrun and Ostry, 2007; Ghosh et al., 2011; Medeiros, 2012; Eller and Urvova, 2012; Baldi and Staehr 2013). Regarding the time span and countries comprised, our work is closely connected to Eller and Urvova (2012) work, who estimate the fiscal reaction function for a panel of eight CESEE countries (Bulgaria, Croatia, the Czech Republic, Hungary, Poland, Romania, Slovakia, Slovenia) and a maximum of 17 years (1995-2011). However, we extend our analysis to include all 21 CESEE countries for the data available in the period 1995-2012. In addition, we recognize that these countries are not homogeneous vis-à-vis a broader economic framework and explore whether the differences in the fiscal reaction exist when membership in EU and exchange rate regime are controlled for. Eventually we analyze if fiscal reaction differs in preLehman and post-Lehman period, when most of the countries in sample were affected by common exogenous shock. 
The work is structured as follows. In the second section, we give broader theoretical framework on relations between primary balance, debt sustainability and cyclical behavior of fiscal policy. In the third section, we present some stylized facts on size and dynamics of primary balance, gross government debt and output gap for given sample of countries. Fourth section deals with specification of econometrical model and estimation issues. Fifth section presents and discusses the results of empirical estimation.

\section{Theoretical Framework: Fiscal Reaction Function, Fiscal Sustainability and Cyclical Behavior of Fiscal Policy}

The discussion on fiscal reaction function is basically discussion on fiscal sustainability and cyclical behavior of fiscal policy, i.e. on relationship between government debt, deficit and GDP growth, having in mind that debt accumulated over time and growth prospects are main drivers of primary balances.

Generally, growth path of the debt could be described by the debt accumulation equation:

$$
D_{t}=D_{t-1}+D e f_{t}
$$

where $D_{t}$ denotes level of government debt at time $t$ and $D e f_{t}$ budget deficit at time $t$. In absolute terms, if government running the budget deficit, this will increase current level of debt. However, in relative terms (relative to current GDP) this is not so straightforward; if GDP grows at high level, share of accumulated debt to GDP in previous year will drop relative to GDP in current year and this drop could offset budget deficit relative to GDP. With GDP growth high enough, it is possible for government to stabilize debt to GDP level in long-run even if it runs the deficit all the time. This could be explained by the following simplified equation (by ignoring time):

$$
d^{*}=\frac{d e f}{g_{r}+\pi}
$$

where $d^{*}$ is long-run equilibrium debt to GDP level, def is budget deficit to GDP, $g_{r}$ and $\pi$ real growth rate of GDP and inflation rate (that in total accounts nominal GDP rate). 
Nevertheless, rise of public debt raises additional concerns regarding the structure of budget deficit. Generally, budget deficit could be decomposed to sum of debt servicing costs $d s c$ and primary deficit $p d$, both given relative to $\mathrm{GDP}^{5}$ :

$$
d e f=d s c+p d
$$

Even if government runs stable level of primary deficit to GDP, budget deficit could increase over time due to an increase in debt servicing costs. If We assume with no loss of generality that debt servicing cost are approximately equal to interest payment for countries that issued debt in domestic currency, debt accumulation equation could be further decomposed (in relative terms) as follows:

$$
d_{t}=\left(1+i_{t}-g_{t}\right) d_{t-1}+p d_{t}
$$

where $i_{t}$ and $g_{t}$ denotes nominal interest and GDP growth rates, respectively, and expression $\left(1+i_{t}-g_{t}\right) d_{t-1}$ now represents stock of accumulated debt enlarged with interest payment, corrected by GDP growth rate which reduces relative debt to GDP ratio ${ }^{6}$.

Furthermore, if we rewriting this equation with primary balance on the lefthand side, it shows in a very straightforward manner that level of debt accumulated and GDP growth are two substantial channels in transmission mechanism that eventually determine primary, and consequently, overall budget deficit. Any other adjustment of primary deficit could be achieved only by increasing government debt.

$$
p d_{t}=d_{t}-\left(1+i_{t}-g_{t}\right) d_{t-1}
$$

In order to expand analysis to encompass cyclical behavior of fiscal policy, primary balance $(p b)$ is further decomposed to the cyclically adjusted primary budget balance and cyclical part of the primary budget balance that automatically reacts to the economic cycle. The cyclically adjusted primary budget balance (capb),

\footnotetext{
${ }^{5}$ In debt sustainability arithmetic, for sake of more convenient intuitive interpretation, it is usual to consider primary deficit instead of primary balance, which means that primary deficit has the positive value if government spending (without interest payments) exceeds revenues.

${ }^{6}$ Difference between interest and growth rate within debt sustainability framework is usually referred in literature as "interest rate-growth differential"
} 
also known as structural balance, indicates discretionary fiscal policy measures because that is not directly affected by the economic cycle. The cyclical part of the primary budget balance $(c p b)$ is an indicator of automatic fiscal stabilizers because it is directly influenced by cyclical fluctuations in the economy. More precisely, automatic stabilizers refer to fiscal categories that automatically react to the economic cycle without any intervention by fiscal policy authorities. (Angelovska Bezovska et al, 2011). This can be quantified by simple equation:

$$
p b_{t}=c a p b_{t}+c p b_{t}
$$

The estimation of cyclically adjusted primary budget balance shows the cyclical behavior of fiscal policy. A fiscal policy can be considered counter-cyclical if it is expansive (capb increases) in the situation of a negative output gap and restrictive (capb decreases) in the situation where the actual growth of GDP is above its potential rate. On the other hand, a fiscal policy is characterized as pro-cyclical if in a situation of a negative output gap the government employs restrictive fiscal instruments and when the fiscal policy reacts in an expansionary way in the situation of a positive output gap, where the actual output exceeds the estimated potential GDP. ${ }^{7}$

\section{Government Debt, Output Gap and Primary Balance in CESEE Countries: Stylized Facts}

For the purpose of analysis between countries, we classified countries into following groups:

Table 1. Classification of the country groups

\begin{tabular}{|c|c|c|}
\hline CESEE & $\begin{array}{l}\text { Central, Eastern and } \\
\text { South Eastern Europe }\end{array}$ & $\begin{array}{l}\text { ALB BIH HRV MKD MNE SRB BGR } \\
\text { CZE HUN POL ROM SVK SVN EST } \\
\text { LVA LTV BLR MDA RUS UKR TUR }\end{array}$ \\
\hline NMS & New EU r & $\begin{array}{l}\text { HRV BGR CZE HUN POL ROM SVK } \\
\text { SVN EST LVA LTV }\end{array}$ \\
\hline NoMS & $\begin{array}{l}\text { CESEE countries out of } \\
\text { European Union }\end{array}$ & $\begin{array}{l}\text { ALB BIH MKD MNE SRB BLR MDA } \\
\text { RUS UKR TUR }\end{array}$ \\
\hline CIS & $\begin{array}{l}\text { Commonwealth of Inde- } \\
\text { pendent Countries - } \\
\text { only European members }\end{array}$ & BLR MDA RUS UKR \\
\hline B5 & Balkan five & ALB BIH MKD MNE SRB \\
\hline
\end{tabular}

Source: Author

\footnotetext{
${ }^{7}$ Adopted from Mencinger and Aristovnik (2013), who provide reasoning on cyclical behavior using cyclically adjusted overall budget balance instead of cyclically adjusted primary budget balance.
} 
Basic classification is related to the distinction between new EU member states and countries out of EU. As some of CESEE countries became Eurozone members in recent years, their decisions on primary and budget balance levels were influenced by Maastricht criteria for Eurozone admission (Mencinger and Aristovnik, 2013). In addition, NMS are generally considered to be more developed than other CESEE countries, and some of them are even regarded as advanced economies by IMF classification (like Estonia and Czech Republic). As we are particularly interested in Balkan region, NoMS group is divided into two sub-groups Balkan five B5 (without Turkey) and European members of the Commonwealth of Independent Countries (CIS).

Before presenting the methodology and empirical results on estimation of fiscal reaction function, we present some stylized facts on expansionary character and cyclical behavior of fiscal policy in CESEE countries. Figure 1 provides a preliminary summary of average primary balance to GDP ratio levels across lagged debt to GDP ratio ${ }^{8}$ categories for a particular sub-group of countries. Lagged debt to GDP ratio observation values are grouped into 4 categories: low levels (below 20\%), middle-low levels (between 20 and 40\%), middle-high levels (between $40 \%$ and $60 \%$ ) and high levels (more than 60\%). Such approach is loosely inspired by Reinhart and Rogoff (2010) famous work, who in similar manner explored influence of public debt levels to GDP growth with the difference that we took smaller values of debt thresholds in regard to generally lower level of indebtedness of CESEE countries relative to advanced countries. The bars show the average primary balance to GDP ratio of four debt categories, distinguishing between the EU new member states (NMS) and CESEE countries out of EU (NoMS). From the Figure 1 one can observe considerable differences and even opposite tendencies ${ }^{9}$ in relation between level of primary balance to GDP and lagged value of debt with very ambiguous patterns of co-movements. However, when all CESEE countries are analyzed, seems that non-linearity pattern of primary balance and lagged debt to GDP co-movements is observed.

\footnotetext{
${ }^{8}$ Lagged debt is used rather than current values which correspond to debt sustainability arithmetic and also empirical specification of fiscal reaction function that is estimated further in the text.

${ }^{9}$ Positive surpluses for NoMS observed in Figure 1 mostly come from CIS countries.
} 
Zdravković A. et al.: Fiscal Reaction Function: Evidences from CESEE countries

Figure 1. Relation between primary balance and different levels of lagged public debt for NMS and NoMS countries

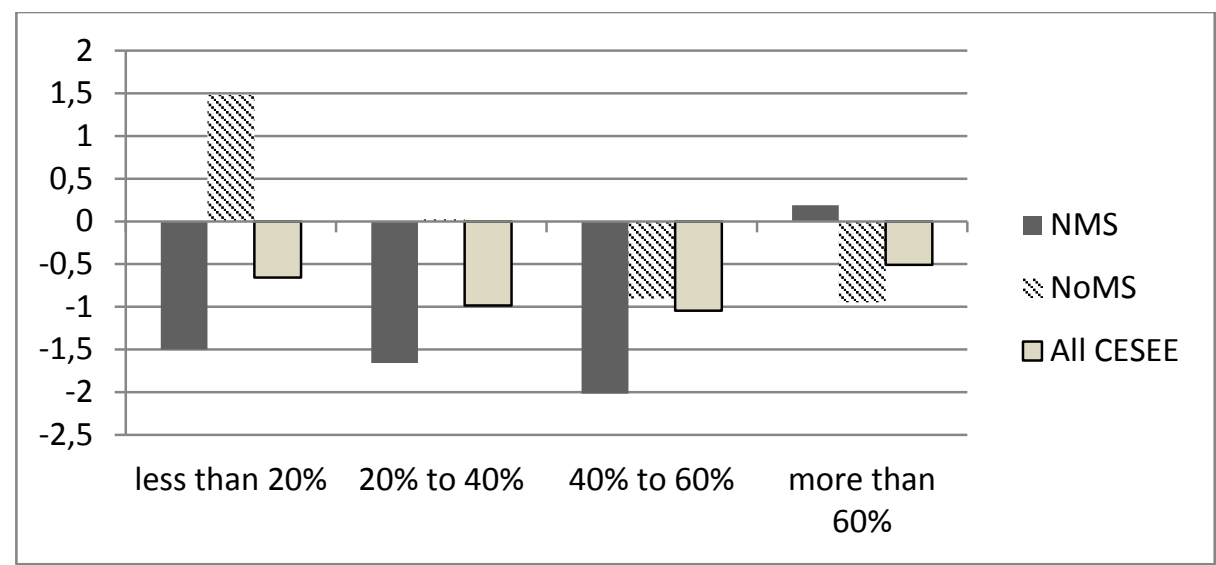

Source: WEO, own calculations

In similar manner, we also analyzed behavior of primary balance relative to output gap ${ }^{10}$. Opposite to previous case, linear relationship between output gap and primary balance is obvious and positive for all CESEE countries and two sub-groups, suggesting countercyclical behavior of primary balance (increasing primary deficits corresponds to negative output gap and increasing primary surplus corresponds to positive output gap).

Figure 2. Relation between primary balance and different levels of output gap for NMS and NoMS countries

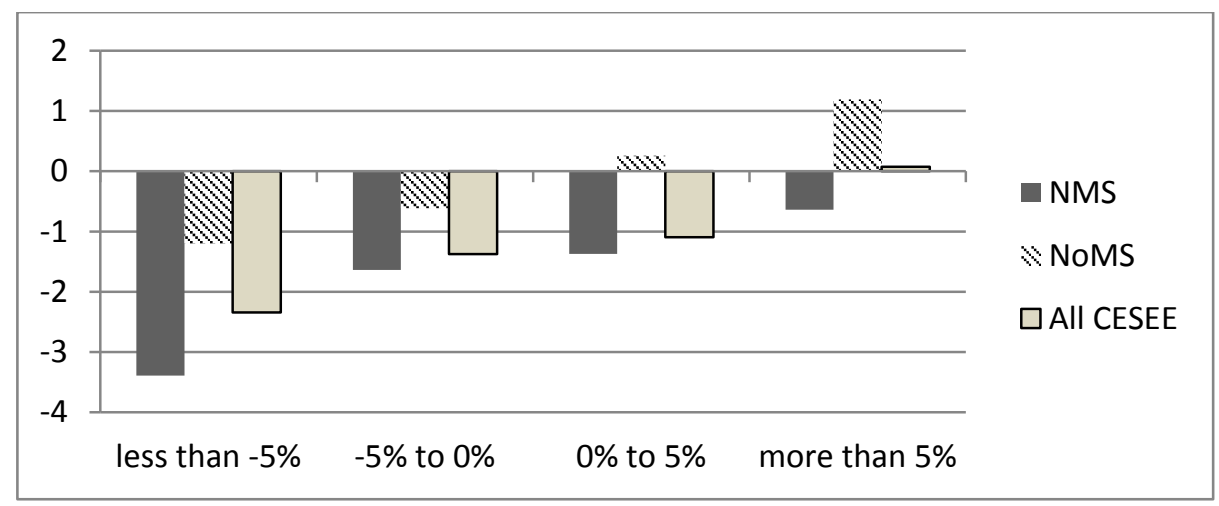

Source: WEO, own calculations

${ }^{10}$ Details on output gap calculations are given in section 4

Industrija, Vol.41, No.4, 2013 


\section{Econometrical model}

In line with theoretical framework and existing literature (Debrun, Celasun and Ostry, 2007; Medeiros, 2012; Eller and Urvova, 2012), we use following specification of fiscal reaction function in order to empirically estimate effects of government debt and output gap on primary balance:

$$
p b_{i, t}=\alpha+\beta d_{i, t-1}+\gamma \operatorname{gap}_{i, t}+X_{i, t} \delta+D_{i, t} \theta+\eta_{i}+\varepsilon_{i, t}
$$

where:

$p b_{i, t}$ is a primary balance to GDP ratio at time $\mathrm{t}$,

$d_{i, t-1}$ is a gross government debt to GDP ratio at time t-1

gap $_{i, t}$ is an estimated output gap as percentage of GDP at time $\mathrm{t}$

$X_{i, t}$ is a vector of control variables

$D_{i, t}$ is a vector of dummy variables

$\eta_{i}$ is a country fixed effect and

$\varepsilon_{i, t}$ is a random error, $\varepsilon_{i, t}-N\left(0, \sigma_{\varepsilon}^{2}\right)$

Estimation of regression equation encounters two possible issues, heterogeneity and endogeneity, which can lead to biased estimation of regression parameters if pooled estimators are used. Heterogeneity is related to the country-specific effects which reflect unobserved differences between the countries that could not be explained by the model variables. This issue is generally overcome by using fixed effects method of econometrical estimation that include a sole dummy variable for each country in sample to capture country specific effects if exist ( $\eta_{i}$ in model specification). Endogeneity refers to the issue of violating the exogeneity property of explanatory variables in the model, which is the important assumption of the unbiased estimation. According to Medeiros (2012), three potential sources of exogeneity exist in the fiscal reaction function specification: contemporaneity of the output gap and the fiscal policy shock $\varepsilon_{i, t}$, dependence of lagged debt on past values of the primary balance (so-called reverse causality issue) and persistence of errors, making lagged debt endogenous. Literature usually proposes GMM, LIML and IV estimation techniques to overcome this issue ${ }^{11}$. However, Eller and Urvova

\footnotetext{
${ }^{11}$ General Method of Moments and Limited Information Maximum Likelihood approach as in Celasun, Debrun and Ostry (2007) or Instrumental variables approach as in Medeiros (2012).
} 
(2102) provide arguments about limited power of GMM estimator when number is large to the number of observations as in our case. Thus, we use fixed effects estimator as a main tool to calibrate model and GMM estimator to check robustness of results.

Previous literature in the field considers large number of control variables, both of economic (like oil prices, CPI inflation, openness) and institutional nature (like index of institutional quality, commitment to IMF programs, fiscal rules index, election indicators). Eller and Urvova (2102) found that institutional factors do not exhibit explanatory power in selected CESSE fiscal reaction function, so we direct our work to testing effects of wide range of macroeconomic variables on primary balance rather than institutional. Similar to previous work, we also explored non-linearites in government debt - primary balance relation. In addition to control variables, we use a set of dummy variables to explore other issues that potentially affect decisions on primary balance, like EU membership, exchange rate regime, post-Lehman recession, state of economy cycle and previous history of debt dynamic.

\section{Empirical results}

The data used in model estimation are obtained from IMF WEO database. Output gap is calculated using HP filter with smoothing parameter set to 100, which is popular choice and conventional wisdom (Choudhary et al. 2013). Time coverage varies across the countries from 18 years $(1995-2012)$ to 9 years $(2004-2012)$ period, regarding the data availability. Data coverage for particular countries is given in annex of the paper.

First we estimated model without control and dummy variables and then experimented with controlling for standard macroeconomic variables, looking for those which increase adjusted $\mathrm{R}$ squared when added and which are the most persistent in size, sign and significance of coefficients estimated in regression. Eventually, we kept inflation, unemployment rate, terms of trade and debt squared which altogether with lagged gross government debt and output gap formed our baseline specification of the empirical model. Table 2 presents results of fixed effects estimation of our baseline regression model with gradual adding of control variables. Additionally, we run pooled and $\mathrm{GMM}^{12}$ regressions to check robustness of the coefficients estimated by FE method.

\footnotetext{
12 In GMM estimation lagged debt and output gap are instrumented by inflation, terms of trade, openness, external demand, unemployment rate and lagged values of primary balance, output gap and lagged debt, similar to Medeiros (2012).
} 
Zdravković A. et al.: Fiscal Reaction Function: Evidences from CESEE countries

Table 2. Estimates of the fiscal reaction function - baseline specification

\begin{tabular}{|c|c|c|c|c|c|c|}
\hline & $\mathrm{FE}$ & & & & Pooled & GMM \\
\hline Lagged GG & $0.0609^{\star \star \star} 0.0514^{\star \star \star}$ & $0.0513^{\star \star \star}$ & $0.0457^{\star \star \star}$ & $0.0766^{\star \star \star}$ & $0.0816^{\star \star \star}$ & $0.1188^{\star \star}$ \\
\hline & $(0.0130) \quad(0.0135)$ & $(0.0131)$ & $(0.0134)$ & $(0.0219)$ & $(0.0216)$ & (0.0469) \\
\hline Output Gap & $\begin{array}{ll}0.2282^{* * *} & 0.2063^{* * *} \\
(0.0360) & (0.0369)\end{array}$ & $\begin{array}{l}0.2919^{\star \star \star \star} \\
(0.0432)\end{array}$ & $\begin{array}{l}0.2853^{\star \star \star \star x} \\
(0.0432)\end{array}$ & $\begin{array}{l}0.2611^{\star \star \star} \\
(0.0450)\end{array}$ & $\begin{array}{l}0.1812^{\star \star \star \star} \\
(0.0394)\end{array}$ & $\begin{array}{l}0.2017^{\star \star \star} \\
(0.0696)\end{array}$ \\
\hline Inflation & $\begin{array}{l}0.0502^{x^{*}} \\
(0.0221)\end{array}$ & $\begin{array}{l}0.0526^{\text {*x }} \\
(0.0212)\end{array}$ & $\begin{array}{l}0.0583^{\text {tx }} \\
(0.0213)\end{array}$ & $\begin{array}{l}0.0597^{\text {*x }} \\
(0.0213)\end{array}$ & $\begin{array}{l}0.0697^{* \pi} \\
(0.0207)\end{array}$ & \\
\hline $\begin{array}{l}\text { Unemployment } \\
\text { rate }\end{array}$ & & $0.0023^{\star \star}$ & $0.0023^{\star \star \star}$ & $0.0021^{\star \star \star}$ & 0.0005 & \\
\hline Terms of trade & & $(0.0006)$ & $\begin{array}{c}(0.0006) \\
-0.0002^{\star \star} \\
(0.00014)\end{array}$ & $\begin{array}{r}(0.0006) \\
-0.00018 \\
(0.00014)\end{array}$ & $\begin{array}{r}(0.0004) \\
-0.00009 \\
(0.00013)\end{array}$ & \\
\hline $\begin{array}{l}\text { Lagged Debt } \\
\text { squared }\end{array}$ & & & & $-0.0540^{*}$ & $-0.082^{\star \star \star}$ & $-0.180^{\star \star \star}$ \\
\hline Const & $\begin{array}{ll}-0.032^{\star \star \star} & -0.032^{\star \star \star} \\
(0.0049) & (0.0048)\end{array}$ & $\begin{array}{c}-0.0612^{\star \star \star} \\
(0.0094)\end{array}$ & $\begin{array}{l}-0.0331^{\star \star} \\
(0.0183)\end{array}$ & $\begin{array}{c}(0.0303) \\
-0.0398 \\
(0.0186) \\
\end{array}$ & $\begin{array}{c}(0.0293) \\
-0.0281^{*} \\
(0.017)\end{array}$ & $\begin{array}{l}(0.0656) \\
-0.029^{\star \star \star} \\
(0.0078)\end{array}$ \\
\hline $\begin{array}{l}\text { Number of } \\
\text { observations }\end{array}$ & 253 & 243 & 243 & 243 & 243 & 201 \\
\hline \multirow{2}{*}{\multicolumn{4}{|c|}{ Note: Standard errors in the parenthesis. }} & 0.4773 & & \\
\hline Levels of signi & ificance: * $p<0.1$, * & $p<0.05$ & ${ }^{*} p<$ & & & \\
\hline
\end{tabular}

Source: Authors

The estimated coefficient for the lagged debt to GDP ratio is positive and varies within the range $0.045-0.061$ when possible non-linearity is not taken into account. This means that increase in gross government debt of 1 percentage point leads to approximately $0.055 \%$ percentage points increase in primary balance in the next year. As already mentioned, we use unadjusted primary balance so it is hard to explicitly distinguish which of its component has more influence on the size, sign and significance of the coefficient estimated. However, we suppose that in pre-Lehman period automatic stabilizers were more important, as high growth rates especially during the boom period in 2000 s open fiscal space for countries to pursue expansionary fiscal policy and decrease primary deficits at the same time. We assume also that in postLehman period the size of this effect has decreased, as most of the CESEE countries continue to increase government debt even at higher rates, but recession of economic activity diminished effects of automatic stabilizers.

When included, lagged debt squared is statistically significant variable with negative sign of the coefficient estimated. Presence of non-linearity in primary balance that we found corresponds to the issue of "fiscal fatigue" in budgetary adjustment process, i.e. at high levels of public debt government needs to 
decrease primary balance in order to preserve debt sustainability. This creates Laffer-type relationship when high levels of debt accumulated implies decline in primary balance response, although it remains positive. Using the quadratic specification of fiscal reaction function with lagged debt squared included, as given below, it is possible to calculate threshold value of government debt when fiscal fatigue occurs:

$$
p b_{i, t}=\alpha+\beta_{1} d_{i, t-1}+\beta_{2} d_{i, t-1}^{2}+\gamma g a p_{i, t}+X_{i, t} \delta+\eta_{i}+\varepsilon_{i, t}
$$

Taking partial derivative with respect to debt, it is convenient to calculate turning point in non-linear form.

$$
\frac{\partial p b_{i, t}}{\partial d_{i, t}}=\beta_{1}-2 \beta_{2} d_{i, t-1}, d_{i, t-1}^{*}=\frac{\beta_{1}}{2 \beta_{2}}
$$

Gosh et al (2011) provide evidences for sample of advanced economies that fiscal fatigue occurs at 90 - 100\% interval of debt to GDP ratio, while Medeiros (2012) found similar threshold interval (80 - 90\%) for sample of $21 \mathrm{EU}$ members. In the same fashion, we found that debt threshold value for fiscal fatigue occurrence is around $70 \%$ for our sample of countries.

The estimated coefficient for the contemporaneous output gap is also positive and varies within the range $0.2-0.3$, which is in line with positive correlation pattern observed in Figure 2. It is worthy to mention here that our values of estimated coefficients for both lagged debt and output gap are remarkably close to those obtained by Eller and Urvova (2012). As Celasun, Debrun and Ostry (2007) noted, fiscal balances react to economic fluctuations both through the discretionary attempts of policymakers to stabilize output fluctuations and the tendency for primary balances to "automatically" decline (increase) during cyclical downturns (expansions). We assume that countercyclical property of primary balance adjustments to contemporaneous output gap is caused by effects of automatic stabilizers rather than actions of policy makers, especially because most of CESEE countries persuaded pro-cyclical fiscal policy during the boom period (IMF, 2012). However, when output gap is under consideration, one should always be cautious that output gap is computed as technical variable obtained by de-trending of given time series rather than frontier value of country production function; therefore, it can be very sensitive to the span of comprised data when calculated.

We augmented our baseline model specification with dummy variables to test several assumptions about possible effects that some other factors could have on fiscal reaction. In order to avoid overestimation of the model with too 
Zdravković A. et al.: Fiscal Reaction Function: Evidences from CESEE countries

many variables, we run separate regressions for each dummy taken into account.

Table 3. Estimates of the fiscal reaction function - augmented specification

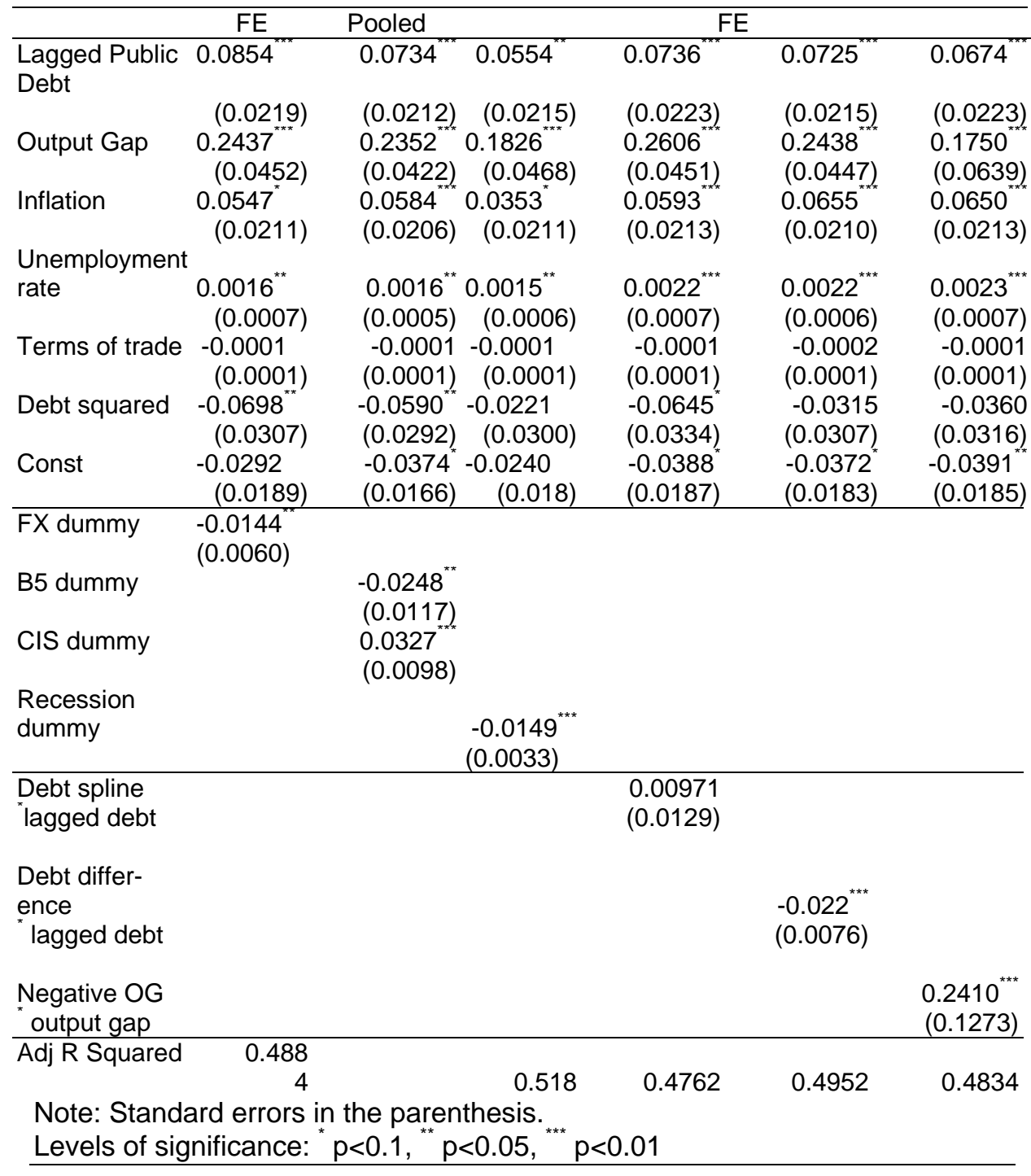

Source: Authors 
It is common wisdom that economies with fixed exchange rate regime have less instruments of monetary policy available. Although mechanism of monetary transmissions is beyond scope of this research, we assume that exchange rate regime could influence adjustment of primary balance. Furthermore, we illustrate differences in fiscal reaction for NMS and NoMS in Figures 1 and 2. Among the NoMS we distinguish CIS and B5 countries as we think that economic and political background of these groups of countries is quite different. As already explained, we assume that in post-Lehman period adjustment of primary balances to explanatory variables declines. All of these assumptions seems to be confirmed by the estimated statistical significance of dummy variables (FX, B5, CIS and Recession dummies).

Further, we consider interaction of some dummy and explanatory variables, as suggested in previous work. Celasun, Debrun and Ostry (2007) include in the model the debt spline at arbitrary selected threshold value of $50 \%$. We use historical average on gross government debt as debt spline threshold, however didn't find empirical evidence of its significance. Also, preceding studies usually consider if response of primary balance to output fluctuation depends on whether a cycle is in boom phase (when output gap is positive) or bust phase (when output gap is negative). We found evidences that countercyclical response of primary balance is more pronounced in economic downturn. Eventually, we assume that not only level of lagged debt is important for primary balance adjustment, but also if the debt previously increase or decrease. Estimation supports this reasoning and negative value of estimated coefficient suggest that previous increase in government debt will have diminishing effect on size of primary balance adjustment next year.

\section{Conclusions}

In this work we analyze how primary balances in CESEE countries adjust to dynamic of gross government debt and economy cycle, based on empirical estimation of fiscal reaction function. Based on sample of 21 CESEE countries for time period 1995-2012, we found evidences that both lagged government debt and output gap are positively related to primary balance, i.e. that any increase (decrease) of debt or output gap will increase (decrease) primary balance in adjustment process. This result is very strong and do not depend neither on econometric estimation method applied nor addition of control variables in the model. Among the many variables that we controlled for, inflation, unemployment rate and terms of trade seems to be most important. Further, we found evidence of non-linear relationship between primary balance and lagged debt, with fiscal fatigue occurrence at $70 \%$ threshold. Estimation of the augmented model shows that countercyclical response of primary balance is more pronounced in economic downturn relative to boom 
in cycle. Eventually, we provide evidences that response of primary balance to lagged debt and output gap is not homogenous across countries and time period in the sample, as well as that it also depends on exchange rate regime.

\section{References:}

Angelovska Bezovska, A., Bogoev, J., Mitreska, A., \& Vojnovik. Kadievska, M. (2011). Investigating the Cyclical Behavior of Fiscal Policy in the Republic of Macedonia during the Period of Transition. Croatian Economic Survey, 13(1), 57-104.

Baldi, G., \& Staehr.K., (2013). The European Debt Crisis and Fiscal Reaction Functions in Europe 2000-2012. German Institute for Economic Research Discussion Papers 1295.

Celasun, O., Debrun, X., \& Ostry.J., (2007). Primary Surplus Behavior and Risks to Fiscal Sustainability in Emerging Market Countries: A 'Fan-Chart' Approach. IMF Staff Paper 53/3..

Choudhary, A., Hanif, N., \& Iqbal.J., (2013). On smoothing macroeconomic time series using HP and modified HP filter. Munich Personal RePEc Archive Paper No. 45630.

Eller, M., \& Urvova.J., (2012). How Sustainable Are Public Debt Levels in Emerging Europe? Focus on European Economic Integration Q4/12. (pp. 48-79). Oesterreichische Nationalbank.

Ghosh, A., Kim, J., Mendoza, E., Ostry, J., \& Qureshi.M., (2011). Fiscal fatigue, fiscal space and debt sustainability in advanced economies. National Bureau of Economic. Research Working Paper $16782 .$.

-International Monetary Fund. (2012). How Emerging Europe Came Through the 2008/09 Crisis.

Medeiros, J. (2012). Stochastic debt simulation using VAR models and a panel fiscal reaction function: Results for a selected number of countries. European Commission Economic Papers 459.

Mencinger, J., \& Aristovnik.A., (2013). Fiscal Policy Stance in the European Union: The Impact of the Euro.Engineering Economics, 24(1), 52-62.

Reinhart, C.M., \& Rogoff, K.S. (2010). Growth in a Time of Debt. American Economic Review, 100(2), 573-578. doi:10.1257/aer.100.2.573 
Zdravković A. et al.: Fiscal Reaction Function: Evidences from CESEE countries

Annex - Data Coverage by Year and Country

\begin{tabular}{|l|r|}
\hline \multicolumn{1}{|c|}{ Country } & Starting year \\
\hline Albania & 1997 \\
\hline Bosnia \& Herzegovina & 2004 \\
\hline Croatia & 2002 \\
\hline Macedonia & 2000 \\
\hline Montenegro & 2002 \\
\hline Serbia & 2002 \\
\hline Bulgaria & 2002 \\
\hline Czech Republic & 1995 \\
\hline Hungary & 1995 \\
\hline Poland & 1995 \\
\hline Romania & 2004 \\
\hline Slovakia & 1997 \\
\hline Slovenia & 1995 \\
\hline Estonia & 2003 \\
\hline Latvia & 2003 \\
\hline Lithuania & 2000 \\
\hline Belarus & 1998 \\
\hline Moldavia & 2004 \\
\hline Russia & 1998 \\
\hline Ukraine & 2004 \\
\hline Turkey & 1997 \\
\hline
\end{tabular}

